JURNAL JENDELA HUKUM

ISSN Cetak \& Online : 2355-5831/2355-9934

\title{
PELAKSANAAN PEMBERIAN IMUNISASI RUBELLA MENURUT HUKUM POSITIF DAN HUKUM ISLAM
}

\author{
Sjaifurrachman \\ Dosen Fakultas Hukum Universitas Wiraraja \\ sjaifurrachman@wiraraja.ac.id
}

\begin{abstract}
ABSTRAK
Pelaksanaan pemberian Imunisasi tersebut juga masih simpang siur artinya vaksin terutama vaksin Rubella yang diberikan juga masih diragukan, diragukan dalam artian apakah vaksin Rubella tersebut benar-benar aman ketika dimasukkan kedalam tubuh mengingat vaksin yang di suntikkan tersebut juga merupakan bakteri, bahkan MUI jelas-jelas menyatakan bahwa vaksin rubella Haram.

Tujuan penelitian ini adalah Untuk menderkripsikan dan menganalis serta memberi pengetahuan mengenai pemberian vaksin rubella menurut hukum positif dan menurut hukum Islam.

Metode pendekatan yang digunakan adalah Pendekatan Perundang-undangan (Statute Approach) dilakukan dengan menelaah seluruh peraturan perundang-undangan yang sekiranya berkaitan dengan judul yang kami angkat diantaranya adalah Undang-undang Nomor 36 tahun 2009 tentang UU kesehatan, surat edaran Nomor HK.02.01/MENKES/444/2018 tentang pelaksanaan kampaye imunisasi measles rubella fase 2 serta Peraturan Mentri Kesehatan Republik Indonesia Nomor No.12 Tahun 2017 tentang penyelenggaraan imunisasi.
\end{abstract}

Kata kunci : Pemberian, Pelaksanaan, Imunisasi. 


\section{JURNAL JENDELA HUKUM}

ISSN Cetak \& Online : 2355-5831/2355-9934

\section{A. PENDAHULUAN}

Pelaksanaan Imunisasi masih simpang siur artinya vaksin terutama vaksin Rubella yang diberikan juga masih diragukan, diragukan dalam artian apakah vaksin Rubella tersebut benar-benar aman ketika dimasukkan kedalam tubuh mengingat vaksin yang di suntikkan tersebut juga merupakan bakteri, artinya bakteri di lawan dengan bakteri.

Menjadi sebuah dilema bagi orang tua mengingat pelaksanaan Imunisasi Rubella tersebut merupakan program yang diwajibkan oleh pemerintah sehingga wajib bagi pihak sekolah ataupun bagi wali murid yang harus merelakan anaknya diberikan Imunisasi Rubella, padahal Majelis Ulama Indonesia (MUI) masih menyatakan bahwa vaksin yang terkandung di dalam Vaksin Rubella dinyatakan haram karena kandungan terdapat kandungan Babi serta organ manusia.

Pemerintah memberikan instruksi agar setiap anak diberikan Imunisasi Rubella, sedangkan vaksin yang diberikan belum mendapatkan label halal dari Majelis Ulama Indonesia, padahal Islam jelas-jelas mengajarkan kepada hambanya agar jangan sampai darah kita bercampur dengan sesuatu yang haram.

\section{B. PEMBahasan}

\section{B.1. Pengaturan pemberian imunisasi} terutama vaksin rubella menurut hukum positif

Dalam rangka upaya pencegahan maka pemerintah menginstruksikan untuk segera memberikan vaksin MR pada anak kisaran usia
9-15 tahun, bahkan juga bagi ibu-ibu yang saat ini sedang dalam mengagendakan kehamilan. Tetapi instruksi dari pemerintah ini yang bahkan mewajibkan anak-anak untuk diberikan vaksin MR ini menuai banyak polemic. Hal ini dikarenakan karena MUI masih menilai vaksin MR ini Haram. Bangsa Indonesia yang mayoritas penduduknya adalah muslim sedikit banyak terganggu dengan adanya pemberian vaksin ini. Dilema, antara haram atau mengikuti program yang diwajibkan oleh pemerintah. Bahkan ancaman yang berikan bagi siapa saja yang menghalanghalangi pemberian vaksin ini ancamannya adalah pidana.

Pemerintah menggunakan undangundang perlindungan anak sebagai acuan bahwa anak berhak mendapatkan kesehatan. Seperti yang tercantum di dalam pasal 8 Undang-undang perlindungan anak yang berbunyi "Setiap anakberhak memperoleh pelayanan kesehatan dan jaminan social sesuai dengan kebutuhan fisik, mental, spiritual dan social”. Dengan adanya pasal ini jelas sudah bahwa Negara menjamin kesehatan anak yang merupakan hak dasar bagi anak. Hal ini dimaksudkan bahwa hak dari anak tersebut tidak bisa dikurangi dan kita sebagai orang tua bertanggung jawab penuh kepada anak-anak kita.

Bahkan di dalam pasal 30 Undangundang Nomor 23 tahun 2002 tentang perlindungan anak menyebutkan bahwa "orang tua yang melalaikan kewajibannya dalam hal ini tidak mengasuh, tidak 
memelihara, tidak mendidik dan tidak melindungi anak, tidak menumbuh kembangkan anak sesuai dengan kemampuan, bakat, dan minatnya dan mencegah terjadinya perkawinan pada usia anak-anak dapat dilakukan tindakan pengawasan atau kuasa asuh orang tua dapat di cabut". Dari dasar inilah pemerintah kemudian mewajibkan bagi setiap orang tua untuk mendukung program pemerintah berkaitan dengan pemberian vaksin MR tersebut.

Polemic yang terjadi saat ini adalah adanya fatwa Majelis Ulama Indonesia yang memberikan fatwa bahwa vaksin MR tersebut adalah haram, sehingga masyarakat kebingungan antara mendukung atau menolak vaksin tersebut karena menurut agama Islam tidak diperkenankan memasukkan barang yang haram ke dalam tubuh. Bahkan menurut Bangkapos.com melaporkan bahwa di Bangka Belitung sosialisasi pemberian imunisasi MR yang telah dilakukan terpaksa di tunda. Menurut Wakil Gubernur Kepulauan Bangka, Abdul Fatah mengatakan bahwa pihaknya menunda sementara pelaksanaan imunisasi Measles Rubella ((MR) lantaran adanya persoalan belum adanya sertifikasi halal vaksin rubella tersebut.

Di dalam peraturan menteri nomor 12 tahun 2017 tentang Imunisasi pasal 4 menyebutkan bahwa :

1. Imunisasi Program terdiri atas:
a. Imunisasi rutin
b. Imunisasi tambahan
c. Imunisasi Khusus

2. Imunisasi Program harus diberikan sesuai dengan jenis vaksin, jadwal atau waktu pemberian yang di tetapkan dalam
Pedoman Penyelenggaraan Imunisasi sebagaimana tercantum dalam lampiran yang merupakan bagian tidak terpisahkan dari peraturan menteri ini.

Dari pasal tersebut berarti bahwa pemberian imunisasi dalam bentuk vaksin diberikan secara rutin, tambahan dan juga khusus. Oleh karena itu pemberian vaksin ini dilakukan secara bertahap, mulai dari tahap 1 sampai pada tahap-tahap berikutnya dan dimulai dari anak yang berusia 9-15 tahun.

Lebih lanjut dalam pasal 5 juga menyebutkan bahwa:

1. Imunisasi rutin dilaksanakan secara terus menerus dan berkesinambungan.

2. Imunisasi rutin terdiri atas imunisasi dasar dan Imunisasi lanjutan

Sedangkan untuk pemberian vaksin MR ini termasuk pada salah satu pemberian imunisasi terhadap penyakit campak, dan salah satu jenis campak jerman (Rubella). Hal ini termaktub jelas di dalam pasal 6 yang berbunyi:

1. Imunisasi dasar sebagaimana dimaksud dalam pasal 5 ayat (2) diberikan pada bayi sebelum berusia 1 tahun.

2. Imunisasi dasar sebagaimana dimaksud pada ayat 1 terdiri atas imunisasi penyakit:
a. Hepatitis B
b. Poliomyelitis
c. Tuberkolusis
d. Difteri
e. Pertusis
f. Tetanus 
g. Pneumonia dan meningitis yang disebabkan oleh hemophilus influenza tipe $b(\mathrm{Hib})$ dan

h. Campak

Untuk siapa saja pemberian vaksin MR tersebut? Karena vaksin MR ini termasuk dalam penyakit campak, maka upaya pencegahannya adalah dengan memberikan imunisasi lanjutan yang diberikan pada anak usia sekolah dasar, seperti yang disebutkan di dalam pasal 7 :

1. Imunisasi lanjutan sebagaimana dimaksu dalam pasal 5 ayat 2 merupakan ulangan imunisasi dasar untuk mempertahankan tingkat kekebalan dan untuk memperpanjang masa perlindungan anak yang sudah mendapatkan imunisasi dasar.

2. Imunisasi lanjutan sebagaimana dimaksud pada ayat 1 diberikan pada :
a. Anak usia bawah dua tahun (Baduta)
b. Anak usia sekolah dasar
c. Wanita usia subur (WUS)

3. Imunisasi lanjutan yang diberikan pada Baduta sebagaimana dimaksud pada ayat 2 huruf a terdiri atas imunisasi terhadap penyakit difteri, pertusis, tetanus, hepatitis B, pneumonia dan meningitis yang disebabkan oleh hemophilus influenza tipe b (hib) serta campak

4. Imunisasi lanjutan yang diberikan pada anak usia sekolah dasar sebagaimana dimaksud pada ayat 2 huruf b terdiri atas imunisasi terhadap penyakit campak, tetanus dan difteri.

5. Imunisasi lanjutan yang diberikan pada anak usia sekolah dasar sebagaimana dimaksud pada ayat 4 diberikan pada bulan imunisasi anak sekolah (BIAS) yang diintegrasikan dengan usaha kesehatan sekolah.

6. Imunisasi lanjutan yang diberikan pada WUS sebagaimana dimaksud pada ayat 2 huruf c terdiri atas Imunisasi terhadap penyakit tetanus dan difteri.

Berdasarkan dari pasal 7 tersebut karena memang penyakit campak atau yang dikenal dengan vaksin (measles), maka yang menjadi target upaya pencegahannya adalah pada anak sekolah dasar. Oleh karena itu tidak asing lagi ketika terlihat anak-anak sekolah berhamburan keluar kelas ketika melihat ada tenaga kesehatan memasuki sekolah, hal ini dikarenakan anak usia tersebut berfikir akan dilakukan imunisasi sehingga banyak anak yang nangis, lari dan lain sebagainya.

Dalam memberikan vaksin yang akan diedarkan kepada masyarakat menteri kesehatan dapat meminta pertimbangan rekomendasi dari Komite Penasehat Ahli Imunisasi Nasional, seperti yang tertuang di dalam peraturan mentri ini di dalam pasal 10 ,

1. Menteri dapat menetapkan jenis imunisasi Program selain di atur dalam Peraturan Menteri ini dengan mempertimbangkan rekomendasi dari Komite Penasehat Ahli Imunisasi Nasional (Indonesian Technical Advisory Group on Immunization)

2. Komite Penasehat Ahli Imunisasi Nasional ((Indonesian Technical Advisory Group on Immunization) sebagaimana dimaksud pada ayat 1 ditetapkan oleh Menteri. 
3. Komite Penasehat Ahli Imunisasi Nasional ((Indonesian Technical Advisory Group on Immunization) sebagaimana dimaksud pada ayat 2 paling sedikit terdiri atas unsure profesi, akademisi, dan peneliti yang memiliki integritas, keahlian, dan atau pengalaman bidang imunisasi di tingkat nasional/internasional.

4. Komite Penasehat Ahli Imunisasi Nasional ((Indonesian Technical Advisory Group on Immunization) memiliki tugas:

a. Memantau dan mengkaji perkembangan keilmuan vaksin baik dari aspek teknologi, produksi, maupun pengembangan vaksin baru serta memperhatikan kondisi yang berkembang di masyarakat

b. Memilih teknologi di bidang imunisasi dan penyakit yang dapat dicegah dengan Imunisasi.

Berdasarkan pada pasal tersebut di atas seharusnya pemerintah terlebih dahulu seharusnya meminta pertimbangan dari Indonesian Technical Advisory Group on Immunization yang berfungsi memiliki control kepada peredaran vaksin yang akan masuk dan akan digunakan kepada manusia sehingga nantinya vaksin yang akan diberikan terlebih dahulu di tes kandungannya sehingga apabila masih terindikasi bahan-bahan yang sekiranya membahayakan atau mengandung zat yang berbahaya sudah seharusnya Indonesian Technical Advisory Group on Immunization memberikan peringatan atau sinyal bahwa barang tersebut dapat atau tidak dapat digunakan sebagai vaksin yang diberikan ataupun tidak dapat diberikan ataupun tidak layak edar seperti vaksin MR ini.

Untuk pelayanan pemberian pelayanan imunisasi di atur lebih lanjut di dalam pasal 25 sampai pada pasal 33 .

Pada pasal 25 menyebutkan bahwa

1) Pelayanan Imunisasi Program dapat dilaksanakan secara massa atau perseorangan

2) Pelayanan Imunisasi Program sebagaimana dimaksud pada ayat (1) dilaksanakan dengan menggunakan pendekatan keluarga untuk meningkatkan akses pelayanan Imunisasi.

3) Pelayanan Imunisasi Program secara massal sebagaimana dimaksud pada ayat (1) dilaksanakan di Posyandu, sekolah, atau pos pelayanan imunisai lainnya.

4) Pelayanan imunisasi program secara perseorangan sebagaimana dimaksud pada ayat (1) dilaksanakan di rumah sakit, Puskesmas, klinik, dan fasiiltas pelayanan kesehatan lainnya.

Dari pasal tersebut dapat disimpulkan bahwa pelayanan imunisasi sebenarnya dapat dilakukan secara massa ataupun secara perorangan tanpa harus menunggu imunisasi yang datang ke sekolah-sekolah. Orang tua dapat mengimunisasi anaknya pada fasilitas pelayanan kesehatan lainnya. Apabila hal tersebut sudah dilakukan maka tidak perlu dilakukan imunisasi yang sama kedua kalinya kepada anak tersebut apabila ada imunisasi yang datang ke sekolah-sekolah dengan memberitahukan kepada pihak sekolah ataupun tenaga kesehatan yang melakukan imunisasi.

Pasal 26 
1) Setiap fasilitas pelayanan kesehatan yang menyelenggarakan pelayanan imunisasi program wajib menggunakan vaksin yang disediakan oleh Pemerintah Pusat.

2) Dikecualikan dari ketentuan sebagaimana dimaksud pada ayat (1):

a. Berdasarkan alasan medis yang tidak memungkinkan diberikan vaksin yang disediakan oleh Pemerintah Pusat yang dibuktikan oleh surat keterangan dokter atau dokumen medis yang sah; atau

b. Dalam hal orang tua/wali anak melakukan penolakan untuk menggunakan vaksin yang disediakan Pemerintah Pusat.

3) Fasilitas pelayanan kesehatan yang melakukan pelanggaran ketentuan sebagaimana dimaksud pada ayat (1) dikenakan sanksi administrative berupa:
a. Teguran tertulis
b. Pencabutan izin

4) Sanksi sebagaimana dimaksud pada ayat (3) diberikan oleh Mentri atau Pemerintah Daerah sesuai dengan kewenangan masingmasing.

Meskipun vaksin yang akan diberikan oleh pemerintah tidak serta merta dapat langsung diberikan pada anak-anak. Dalam hal ini terdapat pengecualian karena di takutkan ada anak yang alergi terhadap vaksin tersebut sehingga tidak diperkenankan pihak tenaga kesehatan memaksa untuk pemberian vaksin. Selain itu juga dalam hal segala tindakan yang berhubungan dengan tindakan medic harus seizin orang tua/wali sehingga orang tua atau walinya tersebut bisa tau apakah anaknya sudah diimunisasi atau belum. Tetapi di Kabupaten
Sumenep jarang sekali tenaga medis yang melakukan imunisasi meminta izin kepada orang tua atau walinya, tahu-tahu anaknya sudah diimunisasi di sekolahnya. Bagaimana seandainya anak tersebut alergi, atau bagaimana seandainya anak tersebut sudah diimunisasi dengan vaksin yang sama. Seharusnya pihak kesehatan yang sudah berkoordinasi dengan pihak sekolah memberikan surat persetujuan untuk dilakukan imunisasi terhadap anaknya. Mau melakukan perjalanan ke luar kota/rekreasi, atau menginap karena ada acara sekolah masih ada surat persetujuan dari orang tua apalagi tindakan medis yang berhubungan dengan kesehatan, harus ada pemberitahuan terlebih dahulu kepada orang tua atau walinya. Sehingga apabila ada kejadian tersebut (tanpa ada persetujuan dari orang tua/walinya dilakukan tindakan imunisasi) maka sesuai dengan pasal diatas fasilitas pelayanan kesehatan telah dianggap melakukan pelanggaran dan dapat dikenakan sanksi administrative berupa teguran tertulis atau pencabutan izin yang dikeluarkan oleh menteri atau Pemerintah daerah sesuai dengan kewenangan masing-masing.

\section{Pasal 27}

1) Pelaksanaan pelayanan Imunisasi rutin harus direncanakan oleh fasilitas pelayanan kesehatan penyelenggara pelayanan imunisasi secara berkala dan berkesimbungan

2) Perencanaan sebagaimana dimaksud pada ayat (1) meliputi jadwal pelaksanaan, 
tempat pelaksanaan dan pelaksana pelayanan imunisasi.

Agar tertib administrasi dan terkontrol dengan baik maka sesuai dengan pasal tersebut diatas maka pelaksanaan imunisasi dilakukan secara berkala dan berkesinambungan baik jadwal, tempat pelaksanaan maupun pelaksana pelayanan imunisasi. Semua harus terencana dengan baik, baik dari pihak sekolah maupun dari dinas kesehatannya apabila dilakukan disekolah-sekolah.

\section{Pasal 29}

1) Pemerintah Daerah Provinsi, Pemerintah Daerah kabupaten/kota dan jajarannya bertanggung jawab menggerakkan peran aktif masyarakat dalam pelaksanaan pelayanan imunisasi program

2) Penggerakkan peran aktif masyarakat sebagaimana dimaksud pada ayat (1) dilaksanakan melalui kegiatan:

a. Pemberian informasi melalui media cetak, media social, media elektronik, dan media luar ruang

b. Advokasi dan sosialisasi

c. Pembinaan kader

d. Pembinaan kepada kelompok binaan balita dan anak sekolah; dan atau

e. Pembinaan organisasi atau lembaga swadaya masyarakat.

Sebagai wujud peran serta dan aktualisasi terhadap masyarakat maka pemerintah wajib menggerakkan peran aktif masyarakat yang diwujudkan dengan adanya pemberitahuan informasi baik di media cetak , media social yang saat ini sangat banyak dinikmati oleh masyarakat, media elektronil ataupun media luar ruang, selain itu juga harus dilakukan sosialisasi terlebih dahulu kepeda masyarakat tentang imunisasi yang akan diberikan. Peneliti melakukan penelitian yang ada di Kabupaten Sumenep sering menjumpai pasal ini jarang digunakan. Kalaupun ada itu hanya informasi di mediamedia elektronik tentang pemberian imunisasi MR yang saat ini diberikan masih belum mendapatkan label halal dari MUI karena terindikasi terdapat bahan yang tidak boleh dikonsumsi oleh umat Islam yaitu babi dan organ manusia.

Tidak adanya sosialisasi yang dilakukan ke sekolah-sekolah yang mengakibatkan banyak anak-anak yang berhamburan keluar bahkan nekat untuk melompati pagar karena ada dinas dari kesehatan yang datang memberikan imunisasi tanpa tahu imunisasi apa yang akan diberikan saat itu.

Pasal 30

Pelayanan imunisasi Program dilaksanakan oleh tenaga kesehatan yang memiliki kompetensi dan kewenangan sesuai dengan ketentuan peraturan per undangundangan

\section{Pasal 31}

Proses pemberian imunisasi harus memperhatikan:

1) Keamanan, mutu, dan khasiat vaksin yang digunakan; dan

2) Penyuntikan yang aman (safety injection) agar tidak terjadi penularan penyakit terhadap tenaga kesehatan yang 
melaksanakan pelayanan imunisasi dan masyarakat serta menghindari KIPI.

Pemerintah sebagai penyedia vaksin MR seharusnya dapat menjamin keamanan, mutu dan khasiat vaksin yang akan digunakan sesuai dengan pasal tersebut diatas. Masalahnya sekarang adalah vaksin MR tersebut masih terindikasi dari bahan babi dan juga organ manusia. Artinya adalah pemerintah tidak bisa menjamin keamanan dan mutu yang diberikan kepada anak-anak. Umat Islam percaya bahwa babi masih mengandung cacing pita yang dapat merusak organ tubuh lainnya serta babi juga di dalam umat Islam termasuk binatang yang haram dikonsumsi.

\section{Pasal 32}

1) Sebelum pelayanan imunisasi program, tenaga kesehatan harus memberikan penjelasan tentang imunisasi meliputi jenis vaksin yang akan diberikan, manfaat, akibat apabila tidak diimunisasi, kemungkinan terjadinya KIPI dan upaya yang harus dilakukan, serta jadwal imunisasi berikutnya

2) Penjelasan sebagaimana dimaksud pada ayat (1) dapat menggunakan alat bantu seperti media komunikasi massa

3) Kedatangan masyarakat di tempat pelayanan imunisasi baik dalam gedung maupun luar gedung setelah diberikan penjelasan sebagaimana dimaksud pada ayat (1) dan ayat (2) merupakan persetujuan untuk dilakukan imunisasi.
4) Dalam pelayanan imunisasi program, tenaga kesehatan harus melakukan penyaringan terhadap adanya kontra indikasi pada sasaran imunisasi.

Hal yang harus dilakukan pertama kali bagi tenaga kesehatan untuk melakukan tindakan imunisasi sesuai pasal 32 tersebut adalah dengan memberikan penjelasan imunisasi yang meliputi jenis vaksin yang akan diberikan, manfaatnya serta akibatnya apabila tidak di imunisasi. Tapi yang terjadi adalah para tenaga kesehatan tersebut langsung datang setelah sebelumnya terlebih dahulu datang dan berkoordinasi terlebih dahulu dengan pihak sekolah tetapi tidak menjelaskan jenis vaksin apa yang akan diberikan baik kepada anak-anak yang masih sekolah apalagi kepada kedua orang tua atau walinya. Mereka datang kemudian langsung memberikan vaksin atau mengimunisasi anak-anak tanpa terlebih dahulu melakukan penyaringan terhadap adanya kontra indikasi pada sasaran imunisasi. Mereka menganggap ketika datang ke pihak sekolah dan di terima oleh sekolah dianggap sudah menyetujui akan dilakukannya tindakan medic atau imunisasi.

Pasal 33

Seseorang atau sekelompok orang yang melakukan tindakan menghalang-halangi penyelenggaraan imunisasi program dapat dikenakan sanksi sesuai dengan ketentuan peraturan perundang-undangan.

Pasal 33 tersebut dapat dijadikan alasan bahwa setiap orang yang menolak tindakan imunsasi pemberian vaksin MR tersebut sebagai tindakan menghalang- 
halangi penyelenggaraan imunisasi program. Bahkan siapapun yang menghalang-halangi pemberian imunisasi tersebut dapat dikenai sanksi sesuai dengan ketentuan peraturan perundang-undangan.

Pasal 44

1) Masyarakat termasuk swasta dapat berperan serta dalam pelaksanaan imunisasi bekerja sama dengan Pemerintah Pusat, Pemerintah Daerah Provinsi, dan Pemerintah Kabupaten/kota.

2) Peran serta masyarakat sebagaimana dimaksud pada ayat (1) dapat diwujudkan melalui:

a. Penggerakkan masyarakat

b. Sosialisasi imunisasi

c. Dukungan fasilitasi penyelenggaraan imunisasi

d. Keikutsertaan sebagai kader; dan atau

e. Turut serta melakukan pemantauan penyelenggaraan imunisasi

Dalam pasal tersebut dapat dianalisis bahwa sebelum dilakukannya tindakan imunisasi yang dalam hal ini pemberian vaksin MR seharusnya masyarakat yang bekerjasama dengan Pemerintah baik di pusat maupun di daerah dapat melakukan berbagai macam cara sebagai betuk peran serta masyarakat. Bentuk tersebut salah satunya adalah sosialisasi terlebih dahulu.

Pencatatan dan Pelaporan

Pasal 45
1) Setiap fasilitas pelayanan kesehatan yang menyelenggarakan pelayanan imunisasi harus melakukan pencatatan dan pelaporan secara rutin dan berkala serta berjenjang kepada Menteri melalui dinas kesehatan provinsi dan dinas kesehatan kabupaten kota.

2) Pencatatan dan pelaporan sebagaimana dimaksud pada ayat (1) meliputi cakupan imunisasi, stok dan pemakaian vaksin, ADS, Safety Box, monitoring suhu, kondisi peralatan Cold Chain dan kasus KIPI atau diduga KIPI.

Dalam pasal tersebut juga jarang sekali dilakukan oleh pihak pelayanan kesehatan melakukan pencatatan secara detail berkaitan dengan imunisasi yang telah dilakukan, bahkan tidak jarang orang tua/ wali masih bertanya kepada anaknya imunisasi apa yang sudah diberikan tadi ketika ada tindakan medis. Padahal pasal 45 (2), pencatatan itu meliputi salah satunya adalah cakupan imunisasi yang sudah diberikan, bukan hanya memberi catatan secara umum, tetapi setiap anak perlu rekam mediknya sehingga orang tua/walinya tahu tindakan berikutnya yang harus dilakukan.

Pasal 46

1) Pelaksana pelayanan imunisasi harus melakukan pencatatan terhadap pelayanan imunisasi yang dilakukan.

2) Pencatatan pelayanan imunisasi rutin dilakukan di buku kesehatan ibu dan anak, buku kohor ibu/bayi/balita, buku rapor kesehatanku, atau buku rekam medic. 
3) Pencatatan pelayanan imunisasi rutin yang dilakukan di fasilitas pelayanan kesehatan swasta wajib dilaporkan setiap bulan ke puskesmas wilayahnya dengan menggunakan format yang berlaku.

4) Pencatatan pelayanan imunisasi tambahan dan khusus dicatat dan dilaporkan dengan format khusus secara berjenjang kepada Menteri melalui dinas kesehatan Pemerintah Daerah provinsi dan Pemerintah Daerah Kabupaten/kota.

Pencatatan tersebut harus terekam selain di dalam buku kesehatan ibu dan anak juga harus ada buku rekam medic yang harus diberikan. Tetapi biasanya yang diberikan itu hanya buku kesehatan ibu dan anak ketika baru lahir setelah itu tidak pernah diminta kembali atau di cek ketika sudah usia sekolah dasar. Sehingga ketika akan diimunisasi anak-anak hanya sekedar mengikuti program dari pemerintah tanpa tahu vaksin apa yang sudah diberikan bahkan manfaatnya apa mereka tidak tahu.

\section{B.2. Pemberian Vaksin Rubella Menurut}

\section{Hukum Islam}

Rakyat Indonesia mayoritas penduduknya adalah muslim yang taat, sehingga apapun yang harus dilakukan harus disesuaikan dengan syariat Islam yaitu Al-quran dan hadist. Apabila tidak sesuai dengan Alquran dan hadist langsung ditolak mentahmentah, seperti pemberian vaksin MR yang saat ini beredar dan menjadi program wajib pemerintah yang masih terindikasi haram karena mengandung babi dan organ manusia, bahkan MUI mengeluarkan fatwa keharaman vaksin ini.

Bagi sebagian umat Islam di Indonesia baik mengkonsumsi secara langsung ataupun menyuntikkan vaksin MR yang terindikasi masih haram mendapat perhatian khusus meskipun ini merupakan program wajib dari pemerintah. Tetapi dengan adanya berita MUI masih belum mengeluarkan fatwa halal maka sebagian masyarakat menolak pemberian vaksin MR tersebut.

Pemerintah seharusnya segera mengambil tindakan tegas apakah vaksin tersebut akan tetap dilaksanakan atau segera dihentikan karena ini sudah melanggar syariat Islam yang telah di percaya secara turuntemurun, yang namanya haram tetaplah haram tanpa terkecuali begitu anggapan masyarakat yang ada di lingkungan patembayan, bukan malah memaksakan agar pemberian vaskin ini berlanjut terus dan menimbulkan pro dan kontra di kalangan masyarakat.

MUI dalam fatwanya Nomor 4 tahun 2003 mengeluarkan pernyataan bahwa: “ Tidak boleh mengkonsumsi dan menggunakan makanan/minuman yang menimbulkan rasa/aroma benda-benda atau binatang yang diharamkan" dalam hal ini vaksin MR masih terindikasi mengandung BABI sehingga diharamkan.

Di dalam Al-quran sendiri yaitu pada Surat Al-baqorah ayat 173 yang artinya "tetapi barang siapa dalam keadaan terpaksa (memakannya) sedang dia tidak menginginkannya dan tidak pula melampaui 
batas maka tidak dosa baginya”. Sehingga dari ayat ini dapat disimpulkan bahwa para ulama menetapkan bahwa "hal yang haram diperbolehkan jika dalam keadaan darurat".

Adapun batasan darurat dapat dipertimbangkan sebagai berikut:

1. sudah terjadi keadaan darurat

2. tidak ada jalan lain untuk mencegah penyakit tersebut

3. dapat mengakibatkan kurasakan tubuh apabila tidak segera dilakukan tindakan medis

4. tidak boleh melanggar akidah dan hak-hak orang lain

5. kadar yang terdapat di dalam kandungan vaksin tersebut sedikit.

6. belum di temukannya obat yang lain

Tetapi yang menjadi pertanyaannya adalah apakah pemberian vaksin tersebut benarbenar darurat? Seharusnya kalau darurat sudah di siarkan di berbagai media baik cetak maupun elektronik bahayanya apabila tidak diimunisasi. Tapi selama ini belum ada informasi darurat berkaitan dengan penyakit campak tersebut, sehingga masyarakat banyak melakukan penolakan atau tidak mengizinkan anaknya di imunisasi.

Ada beberapa pendapat tentang boleh tidaknya berobat menggunakan sesuatu yang haram sehingga pendapat ini menjadi kesepakatan para ulama. Beberapa ulama bahkan masyarakat masih berpegang teguh pada hadist yang artinya "Sesungguhnya Allah telah menurunkan penyakit dan menurunkan obat, serta menyediakan obat bagi setiap penyakit, maka berobatlah, dan jangan berobat dengan sesuatu yang haram". (HR. Abu Dawud).

Jadi jelas disini bahwa Allah telah melarang ummatnya untuk berobat menggunakan yang haram tanpa terkecuali. Apalagi Imunisasi ini masih dalam bentuk pencegahan bukan untuk mengobati penyakit, kenapa harus menggunakan yang haram. Seharusnya pemerintah dapat mencegah dengan pemberian vaksin yang sudah halal atau menggunakan cara-cara yang lain seperti mengkarantina sebagian orang yang terindikasi penyakit campak tersebut. Bahkan hadist lain menyebutkan bahwa "Rasulullah SAW melarang untuk berobat menggunakan barang yang haram" (H.R Abu Hurairah r.a).

\section{KESIMPULAN}

Menurut Peraturan Menteri Kesehatan Republik Indonesia pemberian imunisasi untuk saat ini masih tergolong wajib, artinya setiap anak yang berusia balita sampai pada usia 15 tahun harus sudah terimunisasi khusunya juga vaksin MR atau Rubella. Permen nomor 12 tahun 2017 juga mengatur bagaimana mekanisme pemberian vaksin MR tersebut yang dimulai dari adanya sosialisasi terlebih dahulu baru kemudian dilakukannya tindakan medic (imunisasi).

Pemberian imunisasi ini masih banyak masyarakat yang menolak pemberian vaksin MR tersebut karena di dalam vaksin tersebut masih terindikasi mengandung babi dan organ manusia. Bahkan MUI belum mengeluarkan fatwa halal bagi vaksin MR ini bahkan MUI sempat mengeluarkan fatwa 
haram.

\section{DAFTAR BACAAN}

\section{Buku}

Achadiat, Chrisdiono. M, Pernik-pernik Hukum Kedokteran, Melindungi Pasien dan Dokter. (jakarta: Widya Medika 1996)

A. Hidayat. 2007. Seri Problem Solving tumbuh kembang anak siapa bilang anak sehat pasti cerdas. Jakarta: PT Elex Media

Agung, I Gusti Ngurah, 2001, Statistika Analisis Hubungan Kausal berdasarkan data kategorik. Jakarta: PT Raja Grafindo Perkasa.

A. Aziz Alimul Hidayat, 2009 Asuhan Neonatus bayi dan Balita. Cet 1 Jakarta: Buku Kedokteran EGC.

Cecep Triwibowo, etika dan Hukum Kesehatan, Nuha Medika, Yogyakarta 2014

Soekijo Noto atmodjo, Etika dan Hukum Kesehatan, Rineka Cipta, Jakarta, 2010

Sri Siswati, Etika dan Hukum Kesehatan dalam Perspektif Undang-undang Kesehatan, Rajawali Press, Jakarta, 2013

Suririnah. Buku pintar Mengasah BAtita. Jakarta: PT Gramedia Pustaka Utama

Ta'adi, Hukum Kesehatan : sanksi dan motivasi bagi Perawat, Buku Kedokteran EGC, Jakarta, 2013.

Y. Priyono. Merawat Bayi Tapa Baby Sitter. Jakarta: PT BUKU KITA

Peraturan Perundang-Undangan:

Undang-Undang Nomor 36 tahun 2009 tentang Undang-Undang Kesehatan,

Surat Edaran Nomor HK.02.01/MENKES/444/2018

tentang pelaksanaan kampaye imunisasi measles rubella fase 2

Peraturan Menteri Kesehatan nomor 12 tahun 2017 tentang penyelenggaraan Imunisasi 